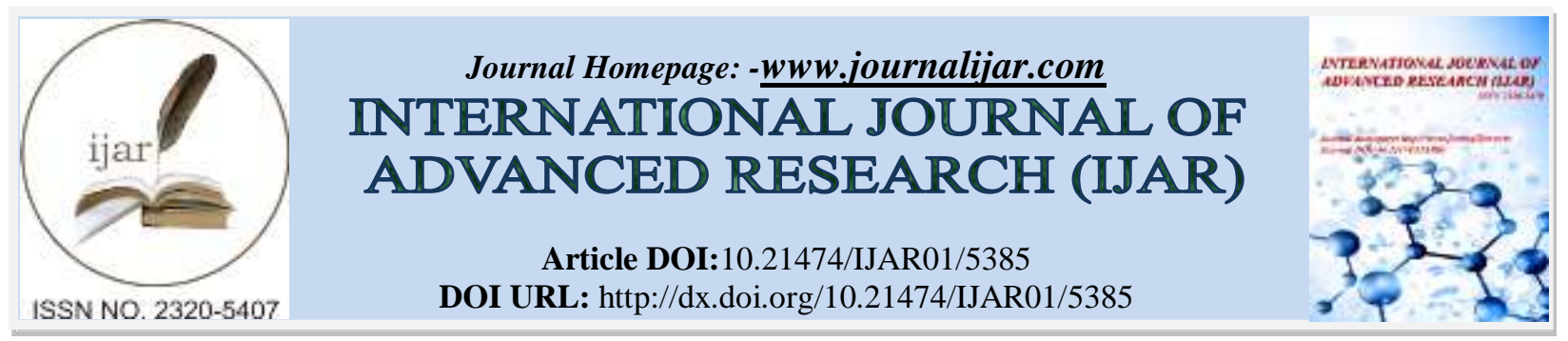

RESEARCH ARTICLE

\title{
GENETICS FOR YIELD AND ITS COMPONENTS IN SESAMUM.
}

\author{
"S. D. Rajput. \\ Department of Agriculture Botany, MPKV, Rahuri (Maharashtra state, India).
}

\section{Manuscript Info}

[.......................

Manuscript History

Received: 10 July 2017

Final Accepted: 12 August 2017

Published: September 2017

Key words:-

Gene effects, generation mean, non-

allelic interaction, scaling test.

\section{Abstract}

Generation mean analysis was carried out to study nature and magnitude of gene effects for yield and its yield component in a cross of sesame (SesamumindicumL.) The parents with their $\mathrm{F}_{1}, \mathrm{~F}_{2}, \mathrm{~B}_{1}$ and $\mathrm{B}_{2}$ were evaluated in replicated trail for ten quantitative traits. The analysis showed that scales A,B and C are highly significant for seed yield/plant and all the ten yield components, indicating the predominance of nonallelic interactions or epistasis of Additive $x$ Additive (i) and Dominance $\mathrm{x}$ Dominance (l) for almost all the ten characters in the cross. Predominance of non-additive (dominance) gene action was prevailed in the expression of seed yield/ plant, its components with duplicate type of epistasis in the cross investigated. Hence, selection should be delayed until virtual homozygosity is attained to achieve the improvement in these traits.

Copy Right, IJAR, 2017,. All rights reserved.

\section{Introduction:-}

Among the five vegetable oilseeds sesame (Sesamum indicumL.) ranking second after groundnut is preferred for its oil and protein in seed. Though India ranks first in area under sesame cultivation in the world. The productivity is very poor $(304 \mathrm{Kg} / \mathrm{ha})$ due to lack of stable high quality seeds with desirable attributes. Sesame is valued not only for its nutritive value but also for its quality and quantity of its oil (44-52\%), which is rich in Vit. E and also contains significant levels of Linoleic acid which controls blood cholesterol levels. The protein content is about $26.5 \%$ (Mosjidis, 1982). Production of sesame seeds can be accomplished either through cytoplasmic male sterility or by emasculation and crossing. The emasculation and crossing is the preferred method in sesame seed production. For genetic improvement of the crop the breeding methods to be employed depends mainly on the nature of the gene action involved in the expression of quantitative trait. Line $\mathrm{x}$ Tester analysis is used to select parents based on their combining ability but cannot detect epistasis. The presence or absence of epistasis can be detected by generation mean analysis using the scale test. For this purpose there is a need to augment its productivity through the development of high yielding varieties. The present study was undertaken to understand the gene effects involved in inheritance of various quantitative traits in sesame to provide a basis for an evaluation of selection methods for the improvement of sesame population.

\section{Materials and Methods:-}

The experimental material for this study consists of the cross viz JLT-9707-2 x VS-07-23 was effected using the parentsJLT-9707-2 and VS-07-23 by hand emasculation and pollination to study the genetics of traits imparting seed yield and its components, for raising $F_{1}$ generation during kharif 2011 . The selfing of $F_{1}$ generation and back crosses were effected to obtain enough self seed and back cross generations during summer 2012. The parents with their $F_{1}$, 
$\mathrm{F}_{2}, \mathrm{~B}_{1}$ and $\mathrm{B}_{2}$ were evaluated in replicated trail during Kharif 2012. The segregating and non-segregating parental populations were cultivated in a Randomized block design with two replications at Post Graduate Research Farm of Department of Botany, Mahatma Phule Agricultural University, Rahuri during kharif 2012. The observation recorded on ten randomly selected plants in $\mathrm{P}_{1}, \mathrm{P}_{2}$ and $\mathrm{F}_{1}, 20$ plants were randomly selected in $\mathrm{F}_{2}, \mathrm{~B}_{1}$ and $\mathrm{B}_{2}$. The traits assessed were days to 50 per cent flowering, days to maturity, Plant height $(\mathrm{cm})$, Number of branches per plant, number of capsules per plant, length of capsule $(\mathrm{cm})$, number of seeds per capsule, seed yield per plant $(\mathrm{g})$, 1000 seed weight $(\mathrm{g})$ and oil content $(\%)$. The mean values, standard errors and variances of the different generations were subjected to weighed least-squares analysis using the scaling test (Mather 1949) and the joint scaling test to estimate gene effects. The genetic effects were estimated using the models suggested by Mather and Jinks (1971) and Jinks and Jones (1958). The significance of the scales and gene effects were tested by using the ttest (Singh and Chaudhary, 1985). The A, B and C scaling tests were carried out for ten traits indicated the presence of non-allelic interactions in the cross. The A and B scaling tests provided the evidence for the presence of additive $\mathrm{x}$ additive $(i)$, additive $\mathrm{x}$ dominance $(j)$ and dominance $\mathrm{x}$ dominance $(l)$ type gene interactions. The $\mathrm{C}$ scaling test provided a test for type 1 epistasis. The type of epistasis was determined only when dominance $(h)$ and dominance $\mathrm{x}$ dominance $(l)$ effects were significant, when these effects had the same sign the effects were complementary while different signs indicated duplicate epitasis (Kearsey and Pooni, 1996).

\section{Results and Discussion:-}

The mean and standard error of the six generations with the cross for ten traits are presented in Table 1, with the means values for the scaling joint scaling tests and their interaction effects being presented in Table 2,3. The hybrids performed better than their respective parents in respect to the length of capsule. in regard to days to 50\% flowering, days to maturity, length of capsule, number of seeds per capsule and oil content the cross showing inferior performance than their respective $\mathrm{P}_{1}$ and $\mathrm{P}_{2}$ generations respectively.

The expected mean $(m)$ of the three possible homozygotes was positive and significant in the cross for all the traits. A simple additive/dominance model was adequate as inferred from the non-significance of all the characters in the cross, an epistatic digenic interaction was found to be a suitable fit, since the scaling and/or joint scaling tests were significant. The additive, dominance and epistatic types of gene interaction in the cross for different trait were found to be different from each other. The dominance $\mathrm{x}$ dominance $(l)$ interaction was larger than the additive $\mathrm{x}$ additive $(i)$ and additive $\mathrm{x}$ dominance $(j)$ effects put together, while for the main effects the dominance component $(h)$ was greater than the additive $(d)$ component. The dominance $(h)$ and dominance $\mathrm{x}$ dominance $(l)$ effects were in the opposite direction, suggesting that duplicate-type epistasis occurred in most cases and indicating predominantly dispersed alleles at the interacting loci (Jinks and Jones 1958). Dominance gene effects was found to be relatively more important, as indicated by the fact that in all cases the dominance $(h)$ values were higher than the additive $(d)$ values.

The 'days to 50\% flowering' trait for the JLT-9707-2 X VS- 07-23cross showed a pronounced additive, dominance and non-allelic interaction additive $\mathrm{x}$ additive $(i)$ type gene interaction. For this trait the dominance $(h)$ and dominance $\mathrm{x}$ dominance $(l)$ gene interaction were found to play a major role. The components $(\mathrm{h}, \mathrm{l})$ are opposite and highly significant in the crossJLT-9707-2 X VS- 07-23 complementary epistatic interaction found. Importance of non additive component was also reported by earlier workers Ramesh et al. (1995), Yamanuraet al. (2009) and Kumar et al. (2012).

The 'days to maturity' trait for the JLT-9707-2 X VS- 07-23cross showed a pronounced additive, dominance and non-allelic interaction additive $\mathrm{x}$ additive $(i)$ type gene interaction. Dominance $(h)$ and dominance $\mathrm{x}$ dominance $(l)$ gene interaction were found to play a major role for this trait. Duplicate epistasis and the predominance of nonadditive gene action was appeared for this trait which confirms the earlier findings Ramesh et al. (1995), Kumar and Vivekanandan (2009), Parameshwrappa et al. (2009), Yamanura et al. (2009) and Kumar et al. (2012).

In case of plant height trait the additive $\mathrm{x}$ additive $(i)$ and additive $\mathrm{x}$ dominance $(\mathrm{j})$ gene effects were significant in the JLT-9707-2 X VS- 07-23cross, This trait also showed duplicate-type epistasis in this cross. The dominance gene component $(\mathrm{h})$ was higher than either the non allelic interactions or additive $(d)$ effects. Although additive $(d)$, additive $\mathrm{x}$ additive $(i)$, additive $\mathrm{x}$ dominance $(j)$ and dominance $\mathrm{x}$ dominance (l) gene effects were significant for the 'plant height' trait non-additive gene effects appear to have been more important, this predominance of dominant gene action is in accordance with the earlier reports of Kumar and Vivekanandan (2009), Parameshwrappa et al. 
(2009), Yamanuraet al. (2009) and Kumar et al. (2012). Duplicate epistasis were reported by Kumar and Ganesan (2004) for this trait.

For the 'number of branches per plant' trait the dominance gene component (h) and additive $\mathrm{x}$ additive ( $i$ ) effect were found to be the most important in the cross, Duplicate type epistasis was predominance in this cross. Duplicate type of epistasis was also reported for this trait by Kumar and Vivekanandan (2009) Parameshwrappa et al. (2009), Yamanura et al. (2009) and Kumar et al. (2012).

In regard to the 'number of capsules per plant' trait dominance gene effects were found to be relatively more important because of the dominance $(h)$ values were higher than the additive $(d)$ in this cross. Non-allelic additive $\mathrm{x}$ additive (i) interactions and duplicate epistasis were observed for this trait in the crossJLT-9707-2 X VS- 07-23. Duplicate epistasis were also reported for this trait by Kumar and Ganesan (2004), Vijayarajan et al. (2007) and Gaikwad et al.(2009).

For the 'seed yield per plant' trait dominance gene effects were found to be relatively more important because of the dominance $(h)$ values were higher than the additive $(d)$ in the cross. Non-allelic additive $\mathrm{x}$ additive (i) interactions and duplicate epistasis were observed for this trait in the cross. The dominance $(h)$ and dominance $\mathrm{x}$ dominance $(l)$ gene effects showed opposite signs, indicating the presence of duplicate dominant epistasis in the expression of this trait similar results also reported for this trait by Kumar and Vivekanandan (2009) Parameshwrappa et al. (2009), Yamanura et al. (2009) and Kumar et al. (2012).

The additive effects and gene interaction dominance $\mathrm{x}$ dominance $(l)$ were observed for length of capsule in the cross, with duplicate epistasis can be exploited effectively by selection for the improvement the characters. The preponderance of additive (d) and dominance $\mathrm{x}$ dominance (l) gene actions with duplicate type of epistasis revealed their potential in controlling this character, which supports the findings of Bakheit et al. (2001), Kumar and Ganesan (2004), Kumar and Vivekanandan (2009) and Sundari et al.(2012). The additive component could be exploited through selection programme.

Dominance and duplicate epistasis were important in the expression of 'number of seeds per capsules' trait in the cross, while dominance $(h)$ and additive $\mathrm{x}$ dominance $(j)$ effects were prominent in the cross JLT-9707-2 X VS- 0723. Non-additive gene action was appeared to be predominant in the expression of this character as has been reported by earlier workers Ramesh et al. (1995), Kumar and Ganesan (2004) and Kumar et al. (2012). Duplicate kind of epistatic interaction was prevailed in the cross. Similar finding were also reported by Sumathi and Muralidharan (2008) and Gaikwadet al. (2009).

The 'weight per 1000 seeds' trait was dominance and duplicate epistasis were important in the JLT-9707-2 X VS07-23cross. However, in the cross non-additive gene action appeared to be predominant, wherein the duplicate type of non allelic interaction was obtained for this trait. Earlier workers Kumar and Vivekanandan (2009) and Kumar $e t$ al. (2012) also revealed the importance of non-additive component for this trait.

The $d, h$ and additive $\mathrm{x}$ additive (i) type gene interactions indicate that this trait is under the control of both fixable and non-fixable gene effects. The additive $\mathrm{x}$ additive (i) type gene interaction and duplicate epistasis seen in this trait suggest the possibilities of obtaining transgressive sergeants in later generations. The additive effects and gene interaction additive $\mathrm{x}$ additive $(i)$ or other type digenic complementary gene interaction can be exploited effectively by selection for the improvement the characters. Use of reciprocal recurrent selection or Bi-parental mating suggested to improve the characters when both additive and non- additive gene effects are involved in the expression of these traits.

Dominance $\mathrm{x}$ dominance $(l)$ non allelic gene interaction play an important role in the inheritance of oil content in the cross with duplicate gene epistasis.

\section{Conclusion:-}

Presence of non-additive gene for days to $50 \%$ flowering, days to maturity, plant height, number of branches per plant, number of capsules per plant, number of seed per capsule, 1000 seed weight and seed yield per plant indicating that conventional selection procedure may not be effective enough for improvement of yield. Therefore postponement of selection in later generations or intermating among the selected segregants followed by one or two 
generations of selfing could be suggested to break the undesirable linkage and allow the accumulation of favourable alleles for the improvement of these traits. The different types of gene effects estimated provided a test for gene action and are useful for analyzing the genetic architecture of a crop so as to further improve desirable traits. The estimates obtained from cross may be unique to that cross and may not be applicable to the parental population. Additive genetic variance formed the major part of the genetic variance for the important yield component trait except length of capsules, number of seeds per capsules and oil content. Therefore genetic improvement in the 'seed yield per plant' trait would be easier through indirect selection for a component traits such as the plant height, number of branches per plant, number of capsules per plant and1000 seed weight than through direct selection for seed yield itself.

Table 1:-Mean performance of different generations for ten characters in the cross JLT-9707-2 X VS- 07-23 of Sesame.

\begin{tabular}{|c|c|c|c|c|c|c|c|c|c|c|}
\hline Generations & $\begin{array}{ll}\text { No. of } \\
\text { days to } \\
50 \quad \% \\
\text { flowering }\end{array}$ & $\begin{array}{l}\text { Days to } \\
\text { maturity }\end{array}$ & $\begin{array}{l}\text { Plant } \\
\text { height } \\
(\mathrm{cm})\end{array}$ & $\begin{array}{l}\text { No. of } \\
\text { branches } \\
\text { per plant }\end{array}$ & $\begin{array}{l}\text { No. of } \\
\text { capsules } \\
\text { per } \\
\text { plant }\end{array}$ & $\begin{array}{l}\text { Length } \\
\text { of } \\
\text { capsule } \\
(\mathrm{cm})\end{array}$ & $\begin{array}{l}\text { No. of } \\
\text { seeds } \\
\text { per } \\
\text { capsule }\end{array}$ & $\begin{array}{l}\text { Seed } \\
\text { yield } \\
\text { per } \\
\text { plant } \\
(\mathrm{g})\end{array}$ & $\begin{array}{l}1000 \\
\text { seed } \\
\text { weight } \\
\text { (g) }\end{array}$ & $\begin{array}{l}\text { Oil } \\
\text { content } \\
(\%)\end{array}$ \\
\hline $\mathbf{P}_{1}$ & $\begin{array}{l}36.00 \\
+0.19\end{array}$ & $\begin{array}{r}83.55 \\
+0.15\end{array}$ & $\begin{array}{l}112.55 \\
+0.54\end{array}$ & $\begin{array}{l}3.35 \\
+0.15\end{array}$ & $\begin{array}{l}97.30 \\
+1.98\end{array}$ & $\begin{array}{l}3.13 \\
+0.02\end{array}$ & $\begin{array}{r}62.15 \\
+0.73 \\
\end{array}$ & $\begin{array}{l}11.39 \\
+0.36\end{array}$ & $\begin{array}{l}2.83 \\
+0.01\end{array}$ & $\begin{array}{l}48.04 \\
+0.01\end{array}$ \\
\hline $\mathbf{P}_{2}$ & $\begin{array}{l}33.80 \\
+0.20\end{array}$ & $\begin{array}{r}79.75 \\
+0.40\end{array}$ & $\begin{array}{l}117.50 \\
+0.52\end{array}$ & $\begin{array}{l}3.80 \\
+0.09\end{array}$ & $\begin{array}{l}85.65 \\
+2.52\end{array}$ & $\begin{array}{l}2.89 \\
+0.02\end{array}$ & $\begin{array}{l}62.15 \\
+1.05\end{array}$ & $\begin{array}{l}11.56 \\
+0.39\end{array}$ & $\begin{array}{l}2.48 \\
+0.01\end{array}$ & $\begin{array}{l}47.10 \\
+0.01\end{array}$ \\
\hline $\mathbf{F}_{1}$ & $\begin{array}{l}30.50 \\
+0.11\end{array}$ & $\begin{array}{r}79.00 \\
+0.20\end{array}$ & $\begin{array}{l}122.05 \\
+1.70\end{array}$ & $\begin{array}{l}4.40 \\
+0.18\end{array}$ & $\begin{array}{l}131.05 \\
+5.44\end{array}$ & $\begin{array}{l}2.65 \\
+0.03\end{array}$ & $\begin{array}{r}68.10 \\
+0.58\end{array}$ & $\begin{array}{r}18.75 \\
+0.28\end{array}$ & $\begin{array}{l}3.24 \\
+0.02\end{array}$ & $\begin{array}{r}44.12 \\
+0.02\end{array}$ \\
\hline $\mathbf{F}_{2}$ & $\begin{array}{r}37.90 \\
+0.40 \\
\end{array}$ & $\begin{array}{r}83.95 \\
+0.46 \\
\end{array}$ & $\begin{array}{l}130.53 \\
+1.76 \\
\end{array}$ & $\begin{array}{l}4.35 \\
+0.17 \\
\end{array}$ & $\begin{array}{r}97.58 \\
+4.12 \\
\end{array}$ & $\begin{array}{l}2.51 \\
+0.04 \\
\end{array}$ & $\begin{array}{r}63.10 \\
+0.72 \\
\end{array}$ & $\begin{array}{r}15.73 \\
+0.63 \\
\end{array}$ & $\begin{array}{l}2.97 \\
+0.04 \\
\end{array}$ & $\begin{array}{r}44.80 \\
+0.40 \\
\end{array}$ \\
\hline $\mathbf{B}_{1}$ & $\begin{array}{l}36.47 \\
+0.10 \\
\end{array}$ & $\begin{array}{l}82.35 \\
+0.08 \\
\end{array}$ & $\begin{array}{l}138.05 \\
+1.21 \\
\end{array}$ & $\begin{array}{l}5.05 \\
+0.16\end{array}$ & $\begin{array}{l}109.85 \\
+2.61 \\
\end{array}$ & $\begin{array}{l}2.65 \\
+0.01 \\
\end{array}$ & $\begin{array}{l}67.20 \\
+0.45 \\
\end{array}$ & $\begin{array}{l}20.14 \\
+0.45 \\
\end{array}$ & $\begin{array}{l}3.15 \\
+0.01\end{array}$ & $\begin{array}{r}4.16 \\
+0.12 \\
\end{array}$ \\
\hline $\mathbf{B}_{2}$ & $\begin{array}{r}34.42 \\
+0.20 \\
\end{array}$ & $\begin{array}{r}80.07 \\
+0.16 \\
\end{array}$ & $\begin{array}{l}129.63 \\
+1.56 \\
\end{array}$ & $\begin{array}{l}5.75 \\
+0.22 \\
\end{array}$ & $\begin{array}{l}115.90 \\
+3.73\end{array}$ & $\begin{array}{l}2.52 \\
+0.02 \\
\end{array}$ & $\begin{array}{l}61.35 \\
+0.34 \\
\end{array}$ & $\begin{array}{l}22.07 \\
+0.36 \\
\end{array}$ & $\begin{array}{l}3.26 \\
+0.01 \\
\end{array}$ & $\begin{array}{l}41.96 \\
+0.01 \\
\end{array}$ \\
\hline
\end{tabular}

Table 2:components.

\begin{tabular}{|c|c|c|c|c|}
\hline \multirow[t]{2}{*}{ Characters } & \multicolumn{4}{|l|}{ Scales } \\
\hline & A & B & $\mathbf{C}$ & $\chi^{2}$ \\
\hline 1.Days to $50 \%$ flowering & $6.45 * *$ & $4.55 * *$ & $20.80 * *$ & $609.164 * *$ \\
\hline 2. Days to maturity & $2.15 * *$ & $1.40 *$ & $14.50 * *$ & $89.152 * *$ \\
\hline 3. Plant height $(\mathrm{cm})$ & $41.50 * *$ & $19.70 * *$ & $47.95 * *$ & $199.610 * *$ \\
\hline 4. No. of branches per plant & $2.35 * *$ & $3.30 * *$ & $1.45 * *$ & $73.607 * *$ \\
\hline 5. No. of capsules per plant & $-8.650 * *$ & $15.10 * *$ & $-54.75 * *$ & $15.367 * *$ \\
\hline 6. Length of capsule $(\mathrm{cm})$ & $-0.485 * *$ & $-0.495 * *$ & $-1.290 * *$ & $139.650 * *$ \\
\hline 7. No. of seeds per capsule & $4.15 * *$ & $-7.55 * *$ & $-\mathbf{8 . 1 0} * *$ & $50.685 * *$ \\
\hline 8. Seed yield per plant (g) & $10.14 * *$ & $13.82 * *$ & $2.46 * *$ & $329.615 * *$ \\
\hline 9. 1000 seed weight $(\mathrm{g})$ & $0.224 * *$ & $0.800 * *$ & $0.070 * *$ & $840.455 * *$ \\
\hline 10. Oil content $(\%)$ & $-3.83 * *$ & $-7.28 * *$ & $-4.19 * *$ & $47076.23 * *$ \\
\hline
\end{tabular}

$*, * *$ significant at $5 \%$ and $1 \%$ level, respectively

TABLE 3:- ESTIMATES OF GENE EFFECTS FOR YIELD AND ITS COMPONENTS IN JLT-9707-2 X VS- 07-23 CROSS OF SESAME

\begin{tabular}{|c|c|c|c|c|c|c|c|c|}
\hline \multirow{2}{*}{\multicolumn{2}{|c|}{ Character }} & \multicolumn{6}{|c|}{ Component } & \multirow{2}{*}{$\begin{array}{l}\text { Type of } \\
\text { epistasis }\end{array}$} \\
\hline & & $\mathrm{m}$ & $\mathrm{d}$ & $\mathrm{h}$ & $\mathrm{i}$ & $\mathrm{j}$ & 1 & \\
\hline 1. & $\begin{array}{l}\text { Days to } 50 \% \\
\text { flowering }\end{array}$ & $\begin{array}{l}37.90 * * \\
(0.40)\end{array}$ & $\begin{array}{l}2.05 * * \\
(0.22)\end{array}$ & $\begin{array}{l}-14.20 * * \\
(1.67)\end{array}$ & $\begin{array}{l}-9.80 * * \\
(1.66)\end{array}$ & $\begin{array}{l}0.950 * * \\
(0.26)\end{array}$ & $\begin{array}{l}-1.20 \\
(1.87)\end{array}$ & Complementary \\
\hline 2. & Days to maturity & $\begin{array}{l}83.95 * * \\
(0.46)\end{array}$ & $\begin{array}{l}2.27 * * \\
(0.18)\end{array}$ & $\begin{array}{l}-13.60 * * \\
(1.90)\end{array}$ & $\begin{array}{l}-10.95 \\
* * \\
(1.88)\end{array}$ & $\begin{array}{l}0.375 * * \\
(0.28)\end{array}$ & $\begin{array}{l}7.40 * * \\
(2.07)\end{array}$ & Duplicate \\
\hline
\end{tabular}




\begin{tabular}{|c|c|c|c|c|c|c|c|c|}
\hline 3. & Plant height $(\mathrm{cm})$ & $\begin{array}{l}130.52 * * \\
(1.76)\end{array}$ & $\begin{array}{l}8.42 * * \\
(1.97)\end{array}$ & $\begin{array}{l}20.27 * * \\
(8.25)\end{array}$ & $\begin{array}{l}13.25^{* *} \\
(8.06)\end{array}$ & $\begin{array}{l}10.90 * * \\
(2.00)\end{array}$ & $\begin{array}{l}-74.45 \\
* * \\
(11.13)\end{array}$ & Duplicate \\
\hline 4. & $\begin{array}{l}\text { No. of branches per } \\
\text { plant }\end{array}$ & $\begin{array}{l}4.35^{* *} \\
(0.17)\end{array}$ & $\begin{array}{l}-0.70^{* *} \\
(0.27)\end{array}$ & $\begin{array}{l}5.02 * * \\
(0.90)\end{array}$ & $\begin{array}{l}4.20 * * \\
(0.88)\end{array}$ & $\begin{array}{l}-0.475 \\
(0.28)\end{array}$ & $\begin{array}{l}-9.85 * * \\
(1.35)\end{array}$ & Duplicate \\
\hline 5. & $\begin{array}{l}\text { No. of capsules per } \\
\text { plant }\end{array}$ & $\begin{array}{l}97.57 * * \\
(4.11)\end{array}$ & $\begin{array}{l}-6.05 \\
(4.55)\end{array}$ & $\begin{array}{l}100.77 * * \\
(19.65)\end{array}$ & $\begin{array}{l}61.20 \\
* * \\
(18.82)\end{array}$ & $\begin{array}{l}-11.87 * \\
(4.82)\end{array}$ & $\begin{array}{l}-67.65 * \\
(27.05)\end{array}$ & Duplicate \\
\hline 6 & $\begin{array}{l}\text { Length of capsule } \\
(\mathrm{cm})\end{array}$ & $\begin{array}{l}2.50 * * \\
(0.04)\end{array}$ & $\begin{array}{l}0.12 * * \\
(0.02)\end{array}$ & $\begin{array}{l}-0.050 \\
(0.17)\end{array}$ & $\begin{array}{l}0.310 \\
(0.17)\end{array}$ & $\begin{array}{l}0.005 \\
(0.02)\end{array}$ & $\begin{array}{l}0.670^{* *} \\
(0.20)\end{array}$ & Duplicate \\
\hline 7 & $\begin{array}{l}\text { No. of seeds per } \\
\text { capsule }\end{array}$ & $\begin{array}{l}\text { 63.10** } \\
(0.72)\end{array}$ & $\begin{array}{l}5.85 * * \\
(0.56)\end{array}$ & $\begin{array}{l}10.65 * * \\
(3.22)\end{array}$ & $\begin{array}{l}4.70 \\
(3.10)\end{array}$ & $\begin{array}{l}5.85^{* *} \\
(0.85)\end{array}$ & $\begin{array}{l}-1.300 \\
(4.05)\end{array}$ & Duplicate \\
\hline 8 & $\begin{array}{l}\text { Seed yield per plant } \\
(\mathrm{g})\end{array}$ & $\begin{array}{l}15.72 * * \\
(0.63)\end{array}$ & $\begin{array}{l}-1.93^{* *} \\
(0.57)\end{array}$ & $\begin{array}{l}28.78 * * \\
(2.80)\end{array}$ & $\begin{array}{l}21.51 * * \\
(2.77)\end{array}$ & $\begin{array}{l}-1.84 * * \\
(0.63)\end{array}$ & $\begin{array}{l}45.48^{* *} \\
(3.51)\end{array}$ & Duplicate \\
\hline 9 & 1000 seed weight $(\mathrm{g})$ & $\begin{array}{l}2.96 * * \\
(0.03)\end{array}$ & $\begin{array}{l}-0.11 * * \\
(0.01)\end{array}$ & $\begin{array}{l}1.54 * * \\
(0.15)\end{array}$ & $\begin{array}{l}0.954 \\
* * \\
(0.15)\end{array}$ & $\begin{array}{l}-0.288 \\
* * \\
(0.01)\end{array}$ & $\begin{array}{l}-1.98 * * \\
(0.16)\end{array}$ & Duplicate \\
\hline 10 & Oil content $(\%)$ & $\begin{array}{l}44.79 * * \\
(0.40)\end{array}$ & $\begin{array}{l}2.20 * * \\
(0.12)\end{array}$ & $\begin{array}{l}-10.38 \\
* * \\
(1.60)\end{array}$ & $\begin{array}{l}-6.93 * * \\
(1.60)\end{array}$ & $\begin{array}{l}1.72 * * \\
(0.12)\end{array}$ & $\begin{array}{l}18.05^{* *} \\
(1.65)\end{array}$ & Duplicate \\
\hline
\end{tabular}

\section{Acknowledgements:-}

We thank to Dr. R.S.Patil, Associate Dean, PGI and Dr.R.W.Bharud, Head, Department of Botany, MPKV, Rahuri for providing infrastructural facilities during course of this research work.

Competing Interest: There are no competing interests to report in the present research

Financing: No funding was received for this research.

\section{References:-}

1. Bakheit B. R, A. A. Ismail, A. A. EL-Shiemy and F. S. Sedek . 2001. Triple test cross analysis in four sesame crosses (Sesamumindicum L.). J. Agric. Sci.,137: 185-193.

2. Cavalli, L.L., 1952. An Analysis of Linkage in Quantitative Inheritance. Lieve, E.C.R. and C.H Waddington, (Eds.), HMSD, London, pp: 135-144.

3. Gaikwad K.B., Lal J.P. and Kumar H. 2009.Genetic architecture of yield and yield attributing characters in Sesame. Crop improve. 36(1):1-5-34-38.

4. Hayman, B.I., 1958. The separation of epistasis from additive and dominant variation in generation mean. Heredity, 12: 31-390.

5. Kumar,-P-S; Puspha,-R; Karuppiah,-P; Ganesan,-J. 2004.Studies on combining ability in sesame (Sesamumindicum L.). Crop. Res.Hisar. 27(1): 99-103.

6. Kumar Bharathi and P.Vivekanandan. 2009.Studies on combining ability studies in sesame (Sesamumindicum L.) Electronic J. Plant Breed (1): 33-36.

7. Kumar Praveen, K. Madhusudan, H. L. Nadaf, R. K. Patil and S. K. Deshpande.2012.Combining ability and gene action studies in inter-mutant hybrids of sesame (SesamumindicumL.)Karnataka J. Agric. Sci.25 (1) : 1-4.

8. Kumar Senthil P. and J. Ganesan. 2004 Generation mean analysis in Sesamum (Sesamumindicum L) Indian J. Agric. Res. 38 (3) : $227-230$.

9. Parameshwarappa S. G., M. G. Palakshappa, K.G. Parameshwarappa and P. M. Salimath. 2009. Genetic investigation of quantitative characters in sesame, SesamumindicumL. . Karnataka J. Agric. Sci., 22 (2): 426427.

10. Ramesh, S., R.A. Sheriff, A.M. Rao, D.L. Savithramma and K. Madhusudan,1995. Generation mean analysis in sesame. Crop Improv., 22: 237-240.

11. Sumathi,-P; Muralidharan,-V. 2008. Study of gene action and heterosis in monostem/shybranching genotypes in sesame (Sesamumindicum L.). Indian-J.Genet.andPlant.Breed.;68(3): 269-274. 
12. Sundari Padma M., Kamala, T. and Y.V. Rao. 2012. Generation Mean Analysis inSesamumindicumL. Asian J. of Agric. Sci. 4(4): 280-286.

13. Vijayrajan, S., K.G. Siruthaiyar and G. Mahalingam, 2007. Generation mean analysis for quantitative traits in sesame (Sesamumindicum L.) crosses. Genet. Mol. Biol., 30(11): 8-84.

14. Yamunara, K. Madhusudanand H. L. Nadaf. 2009. Combining ability and gene action for yield and yield components in sesame (SesamumindicumL.) Karnataka J. Agric. Sci. 22 (2):255-260. 